\title{
Re-creating slum tourism: Perspectives from South Africa
}

\begin{abstract}
Slum tourism is a growing phenomenon in several cities in the global South. The objective in this conceptual paper is to analyse the development and critical challenges around slum tourism in the urban global South and to argue a case for 're-creating' slum tourism by building upon the potential for creative tourism. The focus is upon the 'townships' of South Africa. It is argued that South Africa provides an instructive case study in the international phenomenon of slum tourism and of its potential to be reimagined and developed in a responsible manner, including through an important role for creative tourism. Recommendations are offered for a research agenda on creative slum tourism.
\end{abstract}

Keywords: slum tourism, creativity, townships, creative tourism, economic and physical slum upgrading, South Africa

\section{Introduction}

One critical theme in global scholarship around tourism and poverty, especially in urban areas, is the intensified relationship between tourism and socio-economically marginalized people which can frame the poor as tourist attractions (Frenzel et al., 2015; Rogerson \& Saarinen, 2018). Dovey and King (2012) observe that international tourists have evolved 'a taste for slums' and that urban poverty tours are a tourism product with visits to slums increasingly a 'must do' item on the bucket list of Northern tourists travelling to destinations such as Brazil, India, Kenya, or South Africa (Rogerson, 2004; Freire-Medeiros, 2009; Diekmann \& Hannam, 2012; Magio, 2012; Kieti \& Magio, 2013; Freire-Medeiros, 2014; Nisbett, 2017; Holst, 2018). Newer destinations for slum tours include Egypt, Namibia, Philippines and Zimbabwe among others. Among others Ma (2010) argues that the international spread of slum tourism has been given considerable impetus by the mass media and the appearance of several hit films which depict slum life such as Slumdog Millionaire (Mumbai), District 9 (Johannesburg) and City of God (Rio de Janeiro). Over the past 20 years there has been a surge of scholarship around what has been variously styled as "poverty tourism' and more recently also as 'slum tourism' (Meschkank, 2011; Frenzel \& Koens, 2012; Mekawy, 2012; Frenzel et al., 2012, 2015; Frenzel, 2016; Mkono, 2016; Frenzel, 2017; Nisbett, 2017; Holst, 2018). For one of the earliest academic writers on this topic, Scheyvens (2001: 55), the term poverty tourism describes "forms of travel to impoverished areas which adhere to the principles of alternative tourism". A decade later, Rolfes (2010) styled the growth of poverty tourism as an 'extraordinary' form of tourism.

Several observers point out, however, that the practice of visitations to areas of poverty is not a new phenomenon in cities of the global North, isolating its roots in Victorian London where tours were undertaken around the city's squalid East End by members of the upper class as well as by social reformers and clergymen (Steinbrink, 2012; Frenzel et al., 2015; Frenzel \& Blakeman, 2015; Frenzel, 2016). In contemporary scholarship, the major focus is on cities of 
the global South where slum tours have become highly organized and marketed to visit areas which were previously hidden from the tourist gaze (O’Brien, 2011; Frenzel, 2017; Nisbett, 2017; Holst, 2018). In an ideal sense, Scheyvens (2001) identifies that poverty tourism should be a form of tourism which is both equitable and ethical and which would have several benefits to both tourists and residents inter alia, forge bonds of solidarity between visitors and those visited, promote mutual understanding, enhance the self-sufficiency and selfdetermination of local communities, and maximize local economic, cultural, and social impacts. In addition, the practice of poverty tourism should seek to elevate the awareness of people from privileged backgrounds in the global North about the negative impacts of capitalism, colonialism, and economic inequality which have scarred the well-being and everyday lives of the majority of ordinary citizens of cities in the global South (Scheyvens, 2001).

The task in this paper is to analyse the development and critical challenges around slum tourism in the urban global South and to argue a case for 're-creating' slum tourism by building upon the potential for creative tourism. Turok and Borel-Saladin (2018) observe that extant literature on urban slums emphasises their physical and social problems rather the income trajectories of residents and how this can be improved. Against this backdrop this research seeks to interrogate the possibilities around stimulating economic opportunities accrued to local residents, catalysing physical upgrading in slums, and enhancing representations of slum residents through the promotion of creative forms of tourism. Our lens for developing an agenda for creative slum tourism will be the so-called 'townships' of South Africa, which are one of the major global destinations for slum tourism (Rogerson, 2008; Booyens, 2010; George \& Booyens, 2014; Frenzel et al., 2015; Frenzel, 2016; Muldoon, 2018; Booyens \& Rogerson, in press). Indeed, South Africa provides an instructive case study in the international phenomenon of slum tourism and its potential to be reimagined and developed in a responsible manner, including through an important role for creative tourism. Debates about 'responsible slum tourism' were earlier raised in a useful contribution on the Egyptian experience (Mekawy, 2012). The concept of creative tourism emphasizes active participation in learning experiences on the part of visitors, in addition to creative spectacles and creative spaces or precincts (Richards \& Wilson, 2006; Richards, 2011). Creative spectacles are associated with events and creative spaces with urban development and creative place making (Richards, 2014). In creative economy debates, culture is regarded as a resource for urban livelihoods (Richards, 2014; Duxbury et al., 2016). This paper investigates how culture can be employed to create economic opportunities and stimulate physical upgrading in slum areas which is linked to the concept of resilience gaining tracking in the tourism scholarship (Lew \& Cheer, 2017). Arguably, a focus on creative forms of culture is significant for opening potential economic opportunities and pathways out of poverty for persons living in slums via the diversification of current slum tourism offerings.

The following discussion is organized into three sections. First, a brief contextual overview is given on international scholarship and debates about 'slum tourism'. Second, attention turns to tourism as one element in the changing economic and social character of South Africa's townships. Finally, the third section presents a reflection on 'creativity' in township spaces and then outlines several research issues that merit further investigation in order to solidify the nexus between slum tourism and creative tourism. 


\section{International slum tourism debates}

At its heart, slum tourism is understood as the touristic valorization of poverty-stricken urban areas of the global South (Steinbrink, 2012, 2013; Frenzel, 2016; Nisbett, 2017; Holst, 2018). Essentially, the activity of slum tourism simply describes organized tours to deprived areas (Frenzel, 2016). Within international slum tourism destinations, the relationship between tourism and poverty is re-configured as tourism is no longer simply a vehicle to combat poverty but poverty now becomes an attraction for tourists (Freire-Medeiros, 2014; Frenzel et al., 2015; Frenzel, 2016; Rogerson \& Saarinen, 2018). This said, for its most optimistic observers slum tourism can be an important contributor to the objectives of the Millennium Development Goals and now the United Nations Sustainable Development Goals (O'Brien, 2011; Rogerson \& Saarinen, 2018).

The roots of slum tourism in the global South are generally attributed to several social justice movements which appeared in Brazil and South Africa during the 1990s and began to promote tours, respectively, to the favelas and to townships associated with the anti-apartheid struggle (Frenzel et al., 2015). According to current estimates, as many as one million international tourists incorporate in their itinerary a visit either to a township, a favela, or a slum in some destination of the global South in seeking to observe and 'experience' people living in situations of poverty (Frenzel, 2016, 2017). In addition to guided tours of slums, tourists are offered opportunities to stay overnight in a range of small-scale accommodation service establishments (homestays, bed and breakfasts, backpacker hostels); to experience local restaurants, bars, and hospitality 'drinkatainment'; and occasionally to engage in local festivals or concerts (Bell, 2007; Rogerson, 2008; Booyens, 2010; Koens \& Thomas, 2015; Rogerson \& Mthombeni, 2015; Frenzel, 2016). The widening of product offerings to slum tourists is well-illustrated by the possibility in Soweto even to imbibe 'Soweto Gold' at one of the locality's recently established craft breweries. Globally, the largest numbers of slum tourists flock to the favelas of Brazil, South Africa's townships, or Dharavi, Mumbai, which is reportedly Asia's largest slum (Meschkank, 2011; Nisbett, 2017). Overall, slum tourism is considered "a mass tourism phenomenon occurring only in few destinations and a niche form in a growing number of other destinations" (Frenzel et al., 2015: 237-238).

The phenomenon of slum tourism is galvanizing an international literature across an array of different urban tourism destinations (Rogerson, 2008; Rolfes, 2010; O'Brien, 2011; Dovey \& King, 2012; Dyson, 2012; Frenzel \& Koens, 2012; Magio, 2012; Steinbrink, 2012; Frenzel, 2013, 2016, 2017; Frenzel \& Blakeman, 2015; Frenzel et al., 2015; Holst, 2018). In the expanding scholarship around the topic, the practice of visiting slum areas is not only viewed as a specific type of tourism "but as empirical phenomena that bridge a number of interdisciplinary concerns ranging from international development, political activism, mobility studies to urban regeneration" (Holst et al., 2017: 1). Much controversy surrounds the ethical dimensions of slum tourism with some observers pointing to its voyeuristic appeal "reflecting on why people want to visit slums, what pleasure could be derived from it and whether they should be allowed" (Nisbett, 2017: 38). Holst et al. (2017: 1) maintain that slum tourism is "sometimes cast as a laboratory where the relationships and interactions between the global North and South appear as micro-sociological encounters framed by the apparent concern over inequality". Muldoon (2018) stresses that 'encountering' poverty in slum tourism is a morally fraught experience. Steinbrink (2012) and Frenzel (2016) demonstrate that slum tourism is embedded in post-colonial patterns of discourse in which 'North' and 'South' are specifically reproduced in practices of 'othering'. Different narratives are attached to slum tourism variously as either philanthropic travel or as the organized 
exploitation of poverty. From the latter perspective, it is suggested that by turning people's lives and miseries into a spectacle, slum tours are inherently exploitative and morally questionable at best (Magio, 2012; Frenzel, 2016, 2017; Von Schuckmann \& Barros, 2017). Equally, Sanyal (2015) raises parallel concerns about the 'aestheticization of poverty'. This said, Von Schuckmann and Barros (2017) allude to certain slum tourism practices which are clearly voyeuristic, while others are considered less so depending on how the activities are 'styled'.

For Nisbett (2017: 44) the "normalization, romanticisation, and depoliticization of poverty legitimizes social inequality and diverts attention away from the state and its responsibility for poverty reduction". Accordingly, it is argued that tour operators in slum tourism destinations should seek to nurture a political literacy and assist "tourists to understand poverty by situating it within a politics of place, and in the context of neoliberalism" (Nisbett, 2017: 44). In view of this, the authors observe that slum tourism debates often are dominated by the perceptions of researchers mainly based in global North and analysing Southern slums through 'Western' academic and politicized lenses. Accordingly, there is a disconnect with the 'real' and lived experiences of slum residents, and also a dearth in the literature on how slum residents see themselves and how they wish to be represented. Indeed, Pieterse (2011: 5) argues for a "break with the reductionist tendencies in African urban studies to derive observation and explanation from a materialist reading of difficult living conditions, to foreground instead other ways of understanding the density and spatiality of urban becomings". Therefore, we contend that a danger exists in over-politicizing slum tourism and drawing the attention away from 'people' and their experiences and perceptions - those visiting and those living in slums. Mkono (2016: 208) suggests "what hope does tourism have to transform and better itself towards more human praxis, if its participants are not selfcritical-that is, if they do not continually reflect on their assumptions, worldviews, attitudes and behaviours?". Consequently, a case is made for the practice of reflexivity on the part of slum tourists which entails "interrogating personal misconceptions and allowing selftransformation; embracing ambivalence, complexity and uncertainty; and, critiquing own and others' tourism behaviours" (Mkono, 2016: 217). In addition, it is observed that the "imposition of a negative label of pitiableness" on slum dwellers is inconsistent with and undermines the views that certain residents have of their own existence (Mkono, 2016: 213).

The commodification and commercialization of poverty inevitably has triggered research around who benefits from slum tourism. Indeed, whether slum tourism exerts pro-poor impacts on destinations is deemed a vital issue, not least as its advantages to local communities can offset the dangers of voyeurism. As Frenzel (2013: 117) observes "slum tourism promoters, tour providers as well as tourists claim that this form of tourism contributes to development in slums by creating a variety of potential sources of income and other non-material benefits". For many researchers, the anticipated pro-poor local impacts of developing slum tourism have been elusive for impacted communities. As Kieti and Magio (2013) highlight in the case of Kibera slum, Nairobi the major beneficiaries of slum tourism are non-residents. Likewise, Booyens (2010) observes that most tour operators who take visitors to Soweto are non-locals who capture most of the tourist revenue as part of organised day trips (package tours) taken from Johannesburg or Pretoria. Accordingly, local residents derive little benefit from tourist flows to townships. Essentially, the limited local benefits relate to underlying structures and external control of slum tourism which cause high levels of economic leakage (Frenzel et al., 2015). From an examination of the record of slum tourism development in Kibera and Dharavi, Frenzel and Blakeman (2015) advocate a greater role for informal tour guiding, not least for producing the creation of more intimate and 
authentic encounters. Nevertheless, in cases of local entrepreneurs having initiated small businesses to enter the slum tourism value chain, recorded successes are limited (Koens \& Thomas, 2015, 2016). A lack of access to capital, associated with historical economic exclusion, is underscored as a constraining factor for black female entrepreneurs in Cape Town townships (Hikido, 2017). Nisbett (2017: 39) concludes: "there is currently little evidence to support the economic development argument on a local level other than what appears to be a handful of small-scale and individual cases of entrepreneurship".

\section{South Africa - Township tourism and slum tourism}

One of South Africa's essential contributions to the nomenclature of international human settlements is the locally distinctive phenomenon of the 'township'. The evolution of townships is anchored in South Africa's colonial and apartheid past. Most observers attribute their origins to the drafting of the 1923 Natives (Urban Areas) Act which took the view that the urban areas of South Africa should be regarded as 'European' spaces in which there was no place for 'Natives' (Beavon \& Rogerson, 1990). The 1923 Act entrenched the premise that Black African people would be merely 'temporary sojourners' living in segregated spaces adjacent to urban areas that required their labour (Beavon \& Rogerson, 1990). From its origins in the colonial era, the planning of townships was refined further during the apartheid period as part of wider structures of political and economic subordination of the Black population (Mahajan, 2014).

As a consequence of the logic of townships as dormitory settlements, with minimal infrastructure and comprising only 'temporary people' in urban areas, business development in these spaces was limited by legislation. From 1945, municipal authorities in South African urban areas controlled the allocation of formal trading sites within township areas. Indeed, the legislation constrained the development of formal trading businesses to only "those businesses that would provide nothing more than the daily essentials of living" (Beavon \& Rogerson, 1990: 267). Until 1977 formal businesses in townships were limited to general dealers, butchers, milk shops, and fruit and vegetable shops. The implementation and continued enforcement of this legislation into the apartheid period severely constrained formal business growth in the townships.

Following democratic transition, in 1994 the spatial legacy of apartheid proved difficult to transcend. The segregation of townships was exacerbated by post-apartheid urban development policy. As Philip (2014) points out, for the first decade of South Africa's new democracy the free public housing programme became the de facto urban development strategy of the country. The consequence has been to entrench urban spatial divides with the massive development of housing in post-apartheid townships which "have benefited from only limited spatial planning to enable local economic development-except to support the taxi industry which often provides the only form of transport linking these new-generation townships to city hubs and economic opportunities" (Philip, 2014: 41). Overall, with post1994 democratic changes, although scope existed for the elevation of township economies and the growth of new business development, "many features of the townships' spatial design continued to militate against this" (Philip, 2014: 45). Inevitably, under democracy the essential character of townships as dormitory settlements remained little altered. Local economic development prospects were militated against by either the absence or poor quality of economic infrastructure, locational disadvantages in terms of distance from major 
economic hubs and places of work, and the continued essential subordination of most internal economic activities in townships to an economy outside their boundaries.

It is against this background of townships as economic deserts that considerable interest was aroused in the 1990s by the potential for tourism development in townships as opportunities linked to urban tourism were formerly confined to so-termed 'White spaces' (Rogerson, 2004, 2008). Following political transition, the dropping of economic sanctions, and South Africa's re-entry into the global tourism economy, the townships became more accessible for tourists. With the new 'taste' of international tourists for 'poverty', the niche of township tourism was opened for tourism entrepreneurs (especially in accommodation services) while also allowing black South Africans to recount their stories of the struggles against apartheid to a receptive audience after decades of having their voices suppressed by a hostile government (Scheyvens, 2002). The nature of tourism in Soweto, with its focus the struggle against apartheid, has a strong heritage tourism character even though elements of poverty tourism is also present (Booyens, 2010; Frenzel, 2016). Township tourism as a form of urban heritage tourism has expanded greatly since the 1990s with the most rapid developments occurring in the townships of Soweto, which is part of metropolitan Johannesburg, Khayelitsha and Langa in Cape Town, and Inanda in Durban. Koens and Thomas (2015) maintain that while the expanding economy of township tourism is still viewed as an alternative form of tourism, an estimated 20 to 25 percent of all international tourists to Cape Town now book a township tour which means that the townships are one of the city's most popular tourism attractions.

Township tourism has become recognised as part of a wider scholarship on slum tourism. It should be understood that the formation of townships in South Africa is the result of segregationist planning and polities which grouped people by race and therefore differs from slums elsewhere in cases where these might have developed organically in an unplanned, albeit complex socially-embedded fashion, as the urbanising poor congregates in peri-urban spaces (see Lejano \& Del Bianco, 2018). Accordingly, class differentiation in evident in South Africa's townships. The existence of middle-class neighbourhoods and gentrified tourism precincts in Soweto is inconsistent with the representation of Soweto overall as a 'slum' (Frenzel et al., 2015; Hoogendoorn \& Giddy, 2017). This said, informal settlements within broader township areas of Soweto can be regarded as slums (Turok et al., 2017).

In recent years, Charman (2017) observes that the idea that the economies of townships need to be revitalized has begun to garner significant political traction. Across South Africa, the promotion of 'slum' tourism is incorporated into programmes for tourism-driven local economic development in most of the country's major cities (Rogerson \& Rogerson, 2017).Tourism so far has received little policy focus within a host of new strategic initiatives (taking place particularly in Gauteng province) for township economic regeneration which centre mostly upon industrial development (Rogerson, in press). The new vision for Gauteng province, which is South Africa's economic heartland oriented around Johannesburg, is for encouraging "vibrant and sustainable township enterprises as part of building an inclusive, labour absorbing and growing economy" (Gauteng Province, 2014: 5). Here, strong emphasis is given to transforming townships into sites for productive activities in alignment with South Africa's national goals for 're-industrialization'. Questions about boosting townships as sites for consumption, including for expanded tourism development, are not addressed. 


\section{Re-creating slum tourism}

Product innovation is an essential element for long-term sustainability of tourism destinations. The critical importance of innovation as a whole for tourism development in South Africa has been demonstrated in a number of recent investigations (Booyens, 2016; Booyens \& Rogerson, 2016a, 2016b, 2016c, 2017a, 2017b). It is argued that one basis for expanding township tourism in South Africa is through maximizing the potential for creativity and the development of new innovative creative tourism products. The limited existing research on creative tourism in South Africa suggests that it is mainly concentrated outside of the townships, at least in the documented cases of Johannesburg and Cape Town (Rogerson, 2006; Booyens \& Rogerson, 2015; Gregory \& Rogerson, 2018). This said, there is a historical record on the cultural vibrancy of township life and its importance, especially for arts, music, and entertainment in South Africa (Coplan, 2008). In particular, South Africa's townships have long embodied a creative consumption-focused economy within which a central role has been played by alcohol and drinking venues (shebeens) in a nighttime leisure economy (Rogerson \& Hart, 1986).

Culture has become an important component of local and regional development, and also tourism placemaking policies especially in urban areas (Richards, 2014; Lew, 2017). The basis of creative tourism is culture which is regarded as a resource in creative economy debates (Richards, 2014; Duxbury et al., 2016). It should be mentioned that cultural and creative policies are associated with neo-liberal urban change and intensified uneven economic development as also is witnessed in the South African context (McGuigan, 2005; Booyens, 2012; Florida, 2017). In addition, it is argued that slum formation is strongly linked to neo-liberal urban policies (Linke, 2012; Nisbett, 2017). However, Frenzel (2016) suggests that there are alternatives to Fordist urban planning and that a case can be made for the stimulation of economic opportunities through tourism as an avenue to address pressing socio-economic challenges. Cultural resources are significant for opening potential pathways for spreading the benefits of urban tourism, which has exhibited strong growth over the past three decades, to peripheral township areas in South Africa (see George \& Booyens, 2014; Booyens \& Rogerson, 2019). The emphasis of creative tourism is on creative expressions of culture which include:

1. Active learning experiences, based on culture, whereby tourists become active participants and co-creators of the experiences they consume;

2. Creative precincts linked to cultural and tourism consumption, placemaking and urban development;

3. Creative spectacles and events centred on culture.

The observations presented below focus on townships around Johannesburg and Cape Town, which are South Africa's leading urban tourism destinations (Rogerson \& Rogerson, 2014, 2017). As has been demonstrated for Johannesburg the townships of Soweto mainly are visited by domestic tourists primarily engaged in visiting friends and relatives (Rogerson \& Rogerson, 2016). In light of the growing number of international visitors to townships in South Africa and a number of investigations which observe that visitors to townships are interested in culture and heritage activities and attractions (see Rolfes et al., 2009; Booyens, 2010; City of Cape Town, 2013; Steinbrink, 2013), George and Booyens (2014) argue that there is a latent demand for culture-led, experience-based tourism in townships. However, culture and heritage resources in townships are typically underdeveloped for tourism purposes (Booyens, 2010; George \& Booyens, 2014). In addition, locals benefit little from current configurations of township tourism which mostly take the form of bus tours which 
afford visitors only limited opportunities to interact with local residents (Rolfes et al., 2009; Booyens, 2010; Frenzel et al., 2015; Koens \& Thomas, 2016).

Accordingly, it is suggested that more first-hand experiences between visitors and locals, with a focus on culture and learning, holds the potential for augmenting the township tourism product in a responsible manner (Booyens, 2010; George \& Booyens, 2014; Booyens \& Rogerson, 2015). Booyens (2010) suggests that first-hand experiences should not only enhance the authenticity of visitor experiences to townships, but also create more opportunities for locals to benefit directly. Booyens and Rogerson (2015) observe an emerging form of creative experience-based tourism in Cape Town which is focused on music, arts and crafts, food cuisine, and history and township realities. For instance, visitors are taken to the homes of hosts, often but not exclusively in townships, for experiences vis-àvis local cuisines, art, and music, such as jazz or drumming sessions. Recent developments include the emergence of pop-up dinners and bicycle or walking tours in certain townships. One example is a walking art tour in Langa (Cape Town) as part of the Maboneng Township Art Experience, which also operates in the Alexandra (Johannesburg). Visitors are taken on a walking tour of street art which celebrates local figures (musicians, sport stars, or historical persons) from or associated with Langa, in addition to depictions related to 'struggle' history. Visitors are also taken to home galleries to view art works, interact with some of the hosts, and participate in art making. The initiative is a social enterprise which emphasizes that locals who participate in the initiative benefit directly.

The cultural focus of creative spectacles is performing arts, which are, in most cases, passively consumed by visitors (Richards \& Wilson, 2006). Culture-related events identified in Soweto include book festivals, food festivals, and markets, various music performances, theatre and performance art products, and art and craft markets. One example of a creative spectacle is also organized by the Maboneng Township Art Experience initiative, which hosts an annual cultural festival in both Alexandra and Langa involving the opening of home galleries to visitors for art exhibitions, performances, or storytelling about family histories. Cultural events identified in Cape Town's townships are mostly occasional music concerts and performance art productions, and events associated with food and drink. Examples include the Fringe Festival (performance art festival) in Cape Town, which uses venues in both Langa and Gugulethu for performances, and the Gugulethu Beer and Whisky Festival.

Tourism precincts are the spatial clustering of tourism services such as accommodation establishments, restaurants, shopping facilities (including markets), and other activities and services. Lew (2017) draws attention the 'planned placemaking' approach where urban planning and design feature in tourism placemaking processes. With the creative tourism discourse, the focus is on creating 'more interesting and vibrant places' often in areas where creative firms cluster and intersect with cultural and tourism consumption (Richards, 2014; Lew, 2017). In the case of Soweto, tourism precinct development has expanded in recent years. The most developed precinct is the area around Vilakazi Street in which a house of Nelson Mandela is situated and the nearby Hector Pieterson Museum and Memorial commemorating that tragic events of the 1976 youth uprising, which marked a watershed moment in the struggle against apartheid. Although township tourism product in Soweto centres on struggle attractions, the Vilakazi precinct has been upgraded in the last decade (i.e., improved public spaces, facilities, and facades) and expanded to include a vast array of shops, stalls, and restaurants. Another example of precinct development in Soweto is Kliptown. Although this area has a heritage memorial, a hotel, and a museum, it is poorly developed for tourism overall and mostly operates as a taxi rank and space for informal 
traders. In Cape Town's townships, there are a few heritage monuments and sites as well as some restaurants and coffee shops that are popular among tourists. However, evidence of tourism and/or cultural precinct development is minimal. The best example is the Langa Heritage Precinct. The multi-purpose Guga S'Thebe Arts and Cultural Centre is the anchor of the precinct with a civic centre, the Old Pass Court Museum, several heritage sites, and the emerging Langa Quarter (a township redevelopment project with a focus on culture and tourism) in the vicinity. Arguably, this precinct holds considerable potential for further creative development.

\section{Conclusion}

In reshaping slum tourism in South Africa, there is an important potential role for creative tourism. A re-imagining is needed whereby the emphasis shifts from a narrow focus on struggle heritage and 'viewing poverty' to include contemporary urban cultural heritage more broadly. In other words, less slum tourism and more creative tourism. The implication is that the understanding of cultural heritage in townships needs to be expanded and repackaged as creative tourism, which entails hosting more creative experiences, creating and/or expanding cultural tourism precincts, and promoting cultural events with an emphasis on creativity. It is argued that diversity in the township tourism offering should enable more persons to participate in the tourism economy, offer opportunities for the physical upgrading of townships, and stimulate more domestic visitor consumption and use of leisure spaces. More specifically, creative experiences enable hosts to benefit directly from interactions with visitors, which also enhances the authenticity of visitor experiences. Multi-purpose cultural centres and upgraded precincts should benefit township residents and cultural events, which mostly target local day visitors, domestic tourists as well as local residents, can also be marketed to international visitors to expand the existing creative township tourism offering. Such a re-creation of township tourism not only increases the potential for a variety of opportunities to stimulate economic activities and upgrade tourism spaces, but also negates the view of visits to townships as voyeuristic since the emphasis in no longer on visitors simply viewing slums and poverty, but instead on visitors participating in cultural heritage with locals.

In the light of the observations concerning emerging examples of creative tourism in townships presented in this paper, we argue that creative slum tourism is a topic which is ripe for further investigation. There is a need to embed creative slum tourism in creative tourism debates. Suggested academic and policy related research challenges include:

- Determining the nature and scale of creative tourism activities in slum areas;

- Investigating visitor demand in relation to creative slum tourism offerings;

- Considering how the current slum tourism offerings can be creatively diversified in a responsible manner with an emphasis on accruing benefits to locals, expanding economic opportunities and upgrading slum spaces;

- Determining the nature of cultural representations of people and townships through creative forms of tourism (i.e. how do township residents see themselves, are traditionalist images portrayed or is there evidence of an emerging contemporary urban township culture?); and,

- Interrogating appropriate policy responses to creative slum tourism and creative entrepreneurship in specific contexts. 
Irma Booyens, Human Sciences Research Council, Cape Town, South Africa, and University of Johannesburg, School of Tourism \& Hospitality, Johannesburg, South Africa (irma.booyens@gmail.com)

Christian M. Rogerson, University of Johannesburg, School of Tourism \& Hospitality, College of Business and Economics, Johannesburg, South Africa (crogerson@uj.ac.za)

\section{References}

Beavon, K. \& Rogerson, C. M. (1990) Temporary trading for temporary people: The making of hawking in Soweto. In: Drakakis-Smith, D. (ed.) Economic Growth and Urbanization in Developing Areas, pp. 263286. London, Routledge.

Bell, D. (2007) The hospitable city: Social relations in commercial spaces. Progress in Human Geography, 31, pp. 7-22. DOI: 10.1177/0309132507073526

Booyens, I. (2010) Rethinking township tourism: Towards responsible tourism development in South African townships. Development Southern Africa, 27, pp. 273-287. DOI: 10.1080/03768351003740795

Booyens, I. (2012) Creative industries, inequality and social development: developments, impacts and challenges in Cape Town. Urban Forum, 23, pp. 43-60. DOI: 10.1007/s12132-012-9140-6

Booyens, I. (2016) Global-local trajectories for regional competitiveness: Tourism innovation in the Western Cape. Local Economy, 31(1-2), pp. 142-157. DOI: 10.1177/0269094215618598

Booyens, I. \& Rogerson, C. M. (2015) Creative tourism in Cape Town: An innovation perspective. Urban Forum, 26, pp. 405-424. DOI: 10.1007/s12132-015-9251-y

Booyens, I. \& Rogerson, C. M. (2016a) Tourism innovation in the global South: Evidence from the Western Cape, South Africa. International Journal of Tourism Research, 18, pp. 515-524. DOI: 10.1002/jtr.2071

Booyens, I. \& Rogerson, C. M. (2016b) Unpacking the geography of tourism innovation in the Western Cape Province of South Africa. Bulletin of Geography: Socio-Economic Series, 31, pp. 19-36. DOI: 10.1515/bog2016-0002

Booyens, I. \& Rogerson, C. M. (2016c) Responsible tourism in the Western Cape, South Africa: An innovation perspective. Tourism - An International Interdisciplinary Journal, 64(4), pp. 419-430.

Booyens, I. \& Rogerson, C. M. (2017a) Tourism networking, learning and innovation: evidence from the Western Cape, South Africa. Tourism Geographies, 19(3), pp. 340-361. DOI: 10.1080/14616688.2016.1183142

Booyens, I. \& Rogerson, C. M. (2017b) Managing tourism firms in South Africa for competitiveness: an innovation perspective. Tourism Review International, 21(1), pp. 49-61. DOI: $10.3727 / 154427217 X 14858894687559$

Booyens, I. \& Rogerson, C. M. (in press) Creative tourism: South African township explorations. Tourism Review, 74.

Charman, A. (2017) Micro-enterprise predicament in township economic development: Evidence from Ivory Park and Tembisa. South African Journal of Economic and Management Sciences, 20(1). DOI: 10.4102/sajems.v20i1.1617

City of Cape Town (2013) Tourism Development Framework 2013-2017. Cape Town.

Coplan, D. (2008) In Township Tonight!-South Africa's Black City. Chicago, University of Chicago Press.

Diekmann, A. \& Hannam, K. (2012) Touristic mobilities in India's slum spaces. Annals of Tourism Research, 39(3), pp. 1315-1336. DOI: 10.1016/j.annals.2012.02.005

Dovey, K. \& King, R. (2012) Informal urbanism and the taste for slums. Tourism Geographies, 14(2), pp. 275293. DOI: $10.1080 / 14616688.2011 .613944$

Duxbury, N., Baltà, J., Hosagrahar, J. \& Pascual, J. (2016) Culture in urban development policies: An agenda for local governments. In: UNESCO, Culture: Urban future-Global report on culture for sustainable urban development, pp. 204-211. Paris, UNESCO.

Dyson, P. (2012) Slum tourism: Representing and interpreting "reality" in Dharavi, Mumbai. Tourism Geographies, 14(2), pp. 254-274. DOI: 10.1080/14616688.2011.609900

Florida, R. (2017) The New Urban Crisis: How Our Cities Are Increasing Inequality, Deepening Segregation, and Failing the Middle Class and What We Can Do About It. New York, Basic Books.

Freire-Medeiros, B. (2009) The favela and its touristic transits. Geoforum, 40(4), pp. 580-588. DOI: 10.1016/j.geoforum.2008.10.007

Freire-Medeiros, B. (2014) Touring Poverty. Abingdon, Routledge. DOI: 10.4324/9780203840719

Frenzel, F. (2013) Slum tourism in the context of the tourism and poverty (relief) debate. Die Erde, 144, pp. $117-128$.

Frenzel, F. (2016) Slumming It: The Tourist Valorization of Urban Poverty. London, Zed. 
Frenzel, F. (2017) Tourist agency as valorisation: Making Dharavi into a tourist attraction. Annals of Tourism Research, 66, pp. 159-169. DOI: 10.1016/j.annals.2017.07.017

Frenzel, F. \& Blakeman, S. (2015) Making slums into attractions: The role of tour guiding in the slum tourism development in Kibera and Dharavi. Tourism Review International, 19(1-2), pp. 87-100. DOI: $10.3727 / 154427215 X 14327569678911$

Frenzel, F. \& Koens, K. (2012) Developments in the young field of interdisciplinary tourism research. Tourism Geographies, 14(2), pp. 195-212. DOI: 10.1080/14616688.2012.633222

Frenzel, F., Koens, K. \& Steinbrink, M. (eds.) (2012) Slum Tourism: Poverty, Power and Ethics. London, Routledge. DOI: 10.4324/9780203136751

Frenzel, F., Koens, K., Steinbrink, M. \& Rogerson, C. M. (2015) Slum tourism: State of the art. Tourism Review International, 18, pp. 237-252. DOI: 10.3727/154427215X14230549904017

Gauteng Province (2014) Gauteng Township Economic Revitalisation Strategy 2014-2019. Johannesburg, Gauteng Province Department of Economic Development.

George, R. \& Booyens, I. (2014) Township tourism demand: Tourists' perceptions of safety and security. Urban Forum, 25(4), pp. 449-467. DOI: 10.1007/s12132-014-9228-2

Gregory, J. J. \& Rogerson, C. M. (2018) Suburban creativity: The geography of creative industries in Johannesburg. Bulletin of Geography: Socio-Economic Series, 39, pp. 31-52. DOI: 10.2478/bog-20180003

Hikido, A. (2017) Entrepreneurship in South African township tourism: The impact of interracial social capital. Ethnic and Racial Studies, DOI: 10.1080/01419870.2017.1392026

Holst, T. (2018) The Affective Negotiation of Slum Tourism: City Walks in Delhi. London, Routledge. DOI: $10.4324 / 9781315189598$

Holst, T. E., Frisch, T., Frenzel, F., Steinbrink, M. \& Koens, K. (2017) The complex geographies of inequality in contemporary slum tourism. In: Call for papers for the Association of American Geographers Meeting. Boston. Typescript.

Hoogendoorn, G. \& Giddy, J. K. (2017). 'Does this look like a slum?' Walking tours in the Johannesburg inner city. Urban Forum, 28(3), pp. 315-328. DOI: 10.1007/s12132-017-9307-2

Kieti, D. M. \& Magio, K. O. (2013) The ethical and local resident perspectives of slum tourism in Kenya. Advances in Hospitality and Tourism Research, 1(1), pp. 35-57.

Koens, K. \& Thomas, R. (2015) Is small beautiful?: Understanding the contribution of small businesses in township tourism to economic development. Development Southern Africa, 21(5), pp. 765-784. DOI: $10.1080 / 0376835 X .2015 .1010715$

Koens, K. \& Thomas, R. (2016) "You know that's a rip off": Policies and practices surrounding microenterprises and poverty alleviation in South African township tourism. Journal of Sustainable Tourism, 24(12), pp. 1641-1654. DOI: 10.1080/09669582.2016.1145230

Lejano, R. P. \& Del Bianco, C. (2018) The logic of informality: Pattern and process in a São Paulo favela. Geoforum, 91, pp. 195-205. DOI: 10.1016/j.geoforum.2018.03.005

Lew, A. A. (2017) Tourism planning and place making: place-making or placemaking? Tourism Geographies, 19(3), pp. 448-466. DOI: 10.1080/14616688.2017.1282007

Lew, A. A. \& Cheer, J. (2017) Lessons learned: Globalization, change, and resilience in tourism communities. In: Cheer, J. \& Lew, A. A. (eds.) Tourism, Resilience, and Sustainability: Adapting to Social, Political and Economic Change, pp. 319-323. London, Routledge.

Linke, U. (2012) Mobile imaginaries, portable signs: global consumption and representations of slum life. Tourism Geographies, 14(2), pp. 294-319. DOI: 10.1080/14616688.2012.633218

Ma, B. (2010) A Trip into the Controversy: A Study of Slum Tourism Travel Motivations. Philadelphia, University of Pennsylvania.

Magio, K. (2012) Slum tourism in Kibera, Nairobi, Kenya: Philanthropic travel or organised exploitation of poverty?. Saarbrucken, Lap Lambert.

Mahajan, S. (ed.) (2014) Economics of South African Townships: Special Focus on Diepsloot. Washington DC, The World Bank.

Mekawy, M. A. (2012) Responsible slum tourism: Egyptian experience. Annals of Tourism Research, 39(4), pp. 2092-2113. DOI: 10.1016/j.annals.2012.07.006

Meschkank, J. (2011) Investigations into slum tourism in Mumbai: Poverty tourism and the tensions between different constructions of reality. GeoJournal, 76(1), pp. 47-62. DOI: 10.1007/s10708-010-9401-7

McGuigan, J. (2005) Neo-liberalism, culture and policy. International Journal of Cultural Policy, 11(3), pp. 229-241. DOI: 10.1080/10286630500411168

Mkono, M. (2016) The reflexive tourist. Annals of Tourism Research, 57, pp. 206-219. DOI: $10.1016 /$ j.annals.2016.01.004

Muldoon, M. (2018) Gazing back: A feminist postcolonial lens on tourism in the townships of South Africa, Doctoral thesis, Waterloo ON, Canada, University of Waterloo. 
Nisbett, M. (2017) Empowering the empowered?: Slum tourism and the depoliticization of poverty. Geoforum, 85, pp. 37-45. DOI: 10.1016/j.geoforum.2017.07.007

O'Brien, P. W. (2011) Business, management and poverty reduction: A role for slum tourism? Journal of Business Diversity, 11(1), pp. 33-46.

Philip, K. (2014) A history of townships in South Africa. In: Mahajan, S. (ed.) Economics of South African Townships: Special Focus on Diepsloot, pp. 31-49. Washington DC, The World Bank.

Pieterse, E. (2011) Grasping the unknowable: Coming to grips with African urbanisms. Social Dynamics, 37(1), pp. 5-23. DOI: 10.1080/02533952.2011.569994

Richards, G. (2011) Creativity and tourism: The state of the art. Annals of Tourism Research, 38(4), pp. 12251253. DOI: 10.1016/j.annals.2011.07.008

Richards, G. (2014) Creativity and tourism in the city. Current Issues in Tourism, 17(2), pp. 119-144. DOI: $10.1080 / 13683500.2013 .783794$

Richards, G. \& Wilson, J. (2006) Developing creativity in tourist experiences: A solution to the serial reproduction of culture. Tourism Management, 27, pp. 1209-1223. DOI: 10.1016/j.tourman.2005.06.002

Rogerson, C. M. (2004) Urban tourism and small tourism enterprise development in Johannesburg: The case of township tourism. GeoJournal, 60, pp. 249-257. DOI: 10.1023/B:GEJO.0000034732.58327.b6

Rogerson, C. M. (2006) Creative industries and urban tourism: South African perspectives. Urban Forum, 17 , pp. 149-166. DOI: 10.1007/s12132-006-0003-x

Rogerson, C. M. (2008) Shared growth and urban tourism: Evidence from Soweto. Urban Forum, 19, pp. 395411. DOI: $10.1007 / \mathrm{s} 12132-008-9042-9$

Rogerson, C. M. (in press) The economic development of South Africa's townships. In: Knight, J. \& Rogerson, C. M. (eds.) Geography of South Africa: Contemporary Changes, New Directions. Cham, Springer International. DOI: 10.1007/978-3-319-94974-1 20

Rogerson, C. M. \& Hart, D. M. (1986) The survival of the 'informal sector': The shebeens of Black Johannesburg. GeoJournal, 12(2), pp. 153-166. DOI: 10.1007/BF00216663

Rogerson, C. M. \& Mthombeni, T. (2015) From slum tourism to slum tourists: Township resident mobilities in South Africa. Nordic Journal of African Studies, 24(3-4), pp. 319-338.

Rogerson, C. M. \& Rogerson, J. M. (2014) Urban tourism destinations in South Africa: Divergent trajectories 2001-2012. Urbani izziv, 25(Supplement), pp. S189-S203. DOI: 10.5379/urbani-izziv-en-2014-25supplement-014

Rogerson, C. M. \& Rogerson, J. M. (2016) Intra-urban spatial differentiation of tourism: Evidence from Johannesburg, South Africa. Urbani izziv, 27(2), pp. 125-137. DOI: 10.5379/urbani-izziv-en-2016-2702-004

Rogerson, C. M. \& Rogerson, J. M. (2017) City tourism in South Africa: Diversity and change. Tourism Review International, 21(2), pp. 193-211. DOI: 10.3727/154427217X14984977561745

Rogerson, C. M. \& Saarinen, J. (2018) Tourism and poverty debates in the global South. In: Cooper, C., Gartner, B, Scott, N. \& Volo, S. (eds.) SAGE Handbook of Tourism Management, pp. 22-37. London, Sage. DOI: 10.4135/9781526461490.n4

Rolfes, M. (2010) Poverty tourism: Theoretical reflections and empirical findings regarding an extraordinary form of tourism. GeoJournal, 75(5), pp. 421-442. DOI: 10.1007/s10708-009-9311-8

Rolfes, M., Steinbrink, M. \& Uhl, C. (2009) Townships as Attraction: An Empirical Study of Township Tourism in Cape Town. Potsdam, University of Potsdam.

Sanyal, R. (2015) Slum tours as politics: Global urbanism and representations of poverty. International Political Sociology, 9(1), pp. 93-96. DOI: 10.1111/ips.12080

Scheyvens, R. (2001) Poverty tourism. Development Bulletin, 55, pp. 18-21.

Scheyvens, R. (2002) Tourism for Development: Empowering Communities. Harlow, Prentice Hall.

Steinbrink, M. (2012) 'We did the slum!: Reflections on urban poverty tourism from a historical perspective. Tourism Geographies, 14(2), pp. 1-22. DOI: 10.1080/14616688.2012.633216

Steinbrink, M. (2013) Of voyeuristic safari tours and responsible tourism with educational value: observing moral communication in slum and township tourism in Cape Town and Mumbai. Die Erde, 144(2), pp. 161-174.

Turok, I. \& Borel-Saladin, J. (2018) The theory and reality of urban slums: Pathways-out-of-poverty or cul-desacs?. Urban Studies, 55(4), pp. 767-789. DOI: 10.1177/0042098016671109

Turok, I., Budlender, J. \& Visagie, J. (2017) Urban 'slums' and social mobility. Development Policy Review, DOI: $10.1111 /$ dpr. 12325

Von Schuckmann, J. \& Barros, L. S. G. (2017) From slum tourism to smiley selfies: The role of social identity strength in the consumption of ambiguous experiences. Journal of Consumer Psychology, 28(2), pp. 192-210. DOI: $10.1002 /$ jcpy. 1016 